https://jurnal.univpgri-

palembang.ac.id/index.php/luminous

\title{
PENERAPAN MODEL PEMBELAJARAN DOUBLE LOOP PROBLEM SOLVING (DLPS) TERHADAP KEMAMPUAN PEMECAHAN MASALAH SISWA PADA MATERI BENCANA ALAM
}

\author{
Indriyani ${ }^{1}$, Mochammad Ahied ${ }^{2}$, Irsad Rosidi ${ }^{3}$ \\ 1,2,3 Prodi Pendidikan IPA, Fakultas IImu Pendidikan Universitas Trunojoyo Madura \\ 1'Indri2929@gmail.com
}

\begin{abstract}
Abstrak
Penelitian ini bertujuan untuk mengetahui peningkatan kemampuan pemecahan masalah siswa pada materi bencana alam SMP kelas VII melalui penerapan model pembelajaran Double Loop Problem Solving (DLPS). Data-data yang dikumpulkan dalam penelitian ini berupa data tentang kemampuan pemecahan masalah siswa melalui tes uraian dalam bentuk pretest dan postest, lembar observasi keterlaksanaan pembelajaran guru, dan angket respon siswa. Hasil penelitian menunjukkan bahwa ratarata nilai kemampuan pemecahan masalah siswa pada nilai pretest adalah 50,90 yang tergolong kategori rendah, sedangkan rata-rata nilai posttest siswa adalah 79,49 dengan kategori tinggi. Hasil persentase keterlaksanaan pembelajaran guru adalah 78,23\% dengan kriteria sangat baik. Adapun hasil angket respon siswa terhadap proses pembelajaran mencapai $87,08 \%$ dengan kriteria sangat baik. Berdasarkan data yang diperoleh dari hasil penelitian dapat disimpulkan bahwa penerapan model pembelajaran Double Loop Problem Solving (DLPS) dapat meningkatkan kemampuan pemecahan masalah siswa pada materi bencana alam.
\end{abstract}

Kata kunci : pemecahan masalah, DLPS, bencana alam.

(c) 2020 Pendidikan Fisika FKIP UPGRI Palembang

\section{PENDAHULUAN}

Dunia pendidikan tidak lepas dari adanya pembelajaran yang merupakan jantung dari proses pendidikan. Proses pembelajaran memerlukan adanya inovasi-inovasi baru dalam penyampaian materi, salah satu hal yang harus diperhatikan ialah penerapan model pembelajaran yang dapat melibatkan siswa secara aktif dalam pembelajaran. Berdasarkan hasil penelitian yang dilakukan oleh Nuraini (2016) pembelajaran yang dilakukan oleh guru masih cenderung menggunakan pembelajaran konvensional dan belum melibatkan keaktifan siswa dalam pembelajaran karena pembelajaran masih terpusat pada guru.

Pembelajaran yang terpusat pada guru akan menyebabkan siswa tidak aktif dalam pembelajaran. Siswa yang pasif hanya akan mendengarkan penjelasan guru, sehingga menyebabkan siswa mengalami kesulitan dalam memahami materi, terutama materi IPA pada materi bencana alam. Hal seperti ini akan membuat siswa hanya menghafal konsep dan tidak mampu untuk menumbuhkan keterampilan berpikir siswa, yaitu kemampuan pemecahan masalah dalam kehidupan seharihari. 
Salah satu model pembelajaran yang dapat diterapkan untuk meningkatkan kemampuan pemecahan masalah siswa pada materi bencana alam yaitu model pembelaran Double Loop Problem Solving (DLPS). Siswa dituntut mampu berpikir secara logis dan sistematis, sehingga mampu untuk memecahkan masalah secara bertahap. Menurut Budiyanto (2016) DLPS (Double Loop Problem Solving) adalah variasi pembelajaran dengan pemecahan masalah yang menekankan pada pencarian kausal (penyebab) utama timbulnya masalah. Siswa yang mampu menemukan penyebab dari suatu masalah maka akan mudah untuk menemukan solusi dari masalah yang terjadi. Proses penerapan model pembelajaran Double Loop Problem Solving (DLPS) dalam memecahkan suatu permasalahan, siswa didorong untuk bekerja pada dua loop pemecahan masalah yang berbeda akan tetapi saling berkaitan. Penerapan model pembelajaran Double Loop Problem Solving (DLPS) pada pembelajaran yang dilakukan oleh guru diharapkan dapat membantu dalam penyampaian pelajaran IPA menjadi lebih maksimal, mudah dipahami dan dapat meningkatkan kemampuan pemecahan masalah siswa. Kemampuan pemecahan masalah siswa dalam penelitian ini difokuskan pada materi bencana alam yang meliputi bencana gempa bumi dan gunung berapi.

\section{METODE PENELITIAN}

Jenis penelitian yang digunakan adalah penelitian kuantitatif dengan metode penelitian eksperimen (experimental research). Penelitian pra eksperimen untuk mengetahui penerapan model pembelajaran Double Loop Problem Solving (DLPS) terhadap kemampuan pemecahan masalah siswa. Penelitian dilaksanakan pada bulan Mei 2018 (semester genap) tahun ajaran 2017/2018. Tempat pelaksanaan penelitian yaitu di SMPN 4 Bangkalan. Sampel yang digunakan dalam penelitian ini adalah kelas VIIA yang terdiri dari 26 siswa. Desain penelitian yang digunakan adalah Pre-Experimental (Pra eksperimen) dengan bentuk The One Group Pretest-Posttest Design. Desain penelitian dengan bentuk The One Group Pretest-Post-test Design hanya diterapkan pada satu kelompok, tanpa kelompok pembanding. Desain dalam penelitian ini dapat dilihat pada gambar di bawah ini.

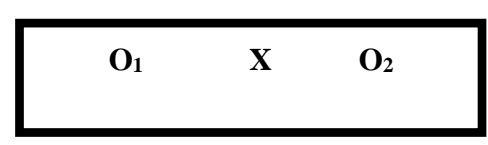

Gambar 1. Desain Penelitian

Keterangan:

$\mathrm{O}_{1}$ : pretest kelas eksperimen

$\mathrm{X}$ : penerapan model pembelajaran Double Loop Problem Solving (DLPS)

$\mathrm{O}_{2}:$ post-test kelas eksperimen

Instrumen pengumpulan data terdiri dari tes kemampuan pemecahan masalah pada materi bencana alam, lembar observasi keterlaksanaan pembelajaran dan angket respon siswa. Tes kemampuan pemecahan masalah digunakan untuk mengukur tingkat kemampuan pemecahan masalah siswa sebelum dan setelah pembelajaran IPA dengan 
menggunakan model pembelajaran Double Loop Problem Solving (DLPS) pada materi bencana alam. Jenis tes yang digunakan dalam penelitian terdiri dari tes sebelum pembelajaran (pretest) dan tes setelah pembelajaran (posttest). Jumlah tes untuk penelitian ini sebanyak 15 soal dalam bentuk uraian. Tes uraian yang digunakan diharapkan mampu membuat siswa tidak hanya mengetahui jawaban benar dan salah, namun siswa mampu memahami langkah-langkah dalam menyelesaikan soal. Kemudian menganalisis pertanyaan dan memberikan jawaban sebagai solusi dari permasalahan, sehingga tes ini dapat mengukur kemampuan pemecahan masalah siswa terutama dalam menghadapi bencana alam yang dapat terjadi dalam kehidupan sehari-hari.

Tes kemampuan pemecahan masalah yang diukur meliputi empat indikator, yaitu: memahami masalah, merencanakan penyelesaian masalah, melaksanakan rencana pemecahan masalah, dan memeriksa kembali proses dan hasil pemecahan masalah. Instrumen disusun berdasarkan dimensi belajar marzano yang merupakan metafora tentang bagaimana otak bekerja selama orang belajar. Dimensi belajar Marzano yang digunakan pada instrumen ini uraian hanya menggunakan 3 tipe berpikir interaktif, yaitu pemerolehan dan pengintegrasian pengetahuan, penggunaan pengetahuan secara bermakna, dan kebiasaan berpikir produktif. Ketuntasan indikator untuk menghitung skor pretes dan posttest pada indikator kemampuan pemecahan masalah dianalisis menggunakan rumus sebagai berikut:

$$
\mathrm{P}=\frac{\mathrm{T}}{\mathrm{N}} \times 100 \%
$$

Keterangan:

$P$ : persentase hasil belajar siswa tiap indikator

$\mathrm{T}$ : jumlah skor seluruh siswa pada indikator

$\mathrm{N}$ : banyaknya indikator

Lembar observasi keterlaksanaan pembelajaran digunakan untuk mengukur keterlaksanaan pembelajaran IPA pada materi bencana alam dengan menggunakan model pembelajaran Double Loop Problem Solving (DLPS). Observasi keterlaksanaan pembelajaran dilakukan selama kegiatan pembelajaran di kelas eksperimen sebanyak tiga pertemuan. Angket respon siswa digunakan untuk mengukur tanggapan siswa terhadap pembelajaran dengan menerapkan model pembelajaran Double Loop Problem Solving (DLPS). Pemberian angket dilakukan di akhir proses pembelajaran pada pertemuan ketiga setelah model pembelajaran Double Loop Problem Solving (DLPS) diterapkan.

Lembar observasi pada penelitian ini dibuat dengan menggunakan skala Guttman. Menurut Sugiyono (2016) Penelitian dengan menggunakan skala Guttman dilakukan apabila ingin mendapatkan jawaban yang tegas terhadap suatu permasalahan. Observasi dilakukan oleh dua orang observer (pengamat) dengan cara memberikan tanda ceklish $(\sqrt{ })$ pada lembar observasi yang terdiri dari dua alternatif pilihan (YA/TIDAK).

Obsevasi keterlaksanaan pembelajaran dilakukan pada setiap pertemuan untuk mengetahui keterlaksanaan pembelajaran dengan menggunakan model pembelajaran Double Loop Problem Solving (DLPS). Hasil 
observasi keterlaksanaan pembelajaran dianalisis dengan rumus sebagai berikut :

$$
\mathrm{K}=\frac{\text { Banyak langkah yang terlaksana }}{\text { Jumlah langkah keseluruhan }} \times 100 \% \text {. }
$$

Sumber: (Rosidi, 2015).

Hasil perhitungan persentase keterlaksanaan pembelajaran akan dianalisis untuk mengetahui kriteria keterlaksanaan pembelajaran menggunakan model pembelajaran Double Loop Problem Solving (DLPS) pada materi bencana alam. Kriteria persentase keterlaksanaan pembelajaran tersebut dapat dilihat pada tabel dibawah ini.

Tabel 1. Kriteria Keterlaksanaan Pembelajaran

\begin{tabular}{ccc} 
No & $\begin{array}{c}\text { Persentase } \\
\text { Keterlaksanaan }\end{array}$ & Kriteria \\
\hline 1 & $75 \%<\mathrm{K} \leq 100 \%$ & Sangat Baik \\
\hline 2 & $50 \%<\mathrm{K} \leq 75 \%$ & Baik \\
\hline 3 & $25 \%<\mathrm{K} \leq 50 \%$ & Cukup Baik \\
\hline 4 & $0 \% \leq \mathrm{K} \leq 25 \%$ & $\begin{array}{c}\text { Kurang Baik } \\
\end{array}$
\end{tabular}

Angket (kuesioner) pada penelitian ini dibuat dengan menggunakan skala likert. Skala likert digunakan untuk mengukur sikap, pendapat, dan persepsi seseorang atau sekelompok orang tentang fenomena sosial (Sugiyono, 2016). Siswa memberikan respon dengan cara memberikan tanda centang $(\sqrt{ })$ pada lembar angket yang berisi 20 penyataan. Masing-masing pernyataan yang terdapat pada angket respon siswa memiliki empat jawaban yang terdiri dari: Sangat Setuju (SS), Setuju (S), Tidak Setuju (TS) dan Sangat Tidak Setuju (STS). Pernyataan berskala positif skor jawaban adalah: $\mathrm{SS}=4, \mathrm{~S}=3$, TS $=2$ dan STS $=1$, sedangkan penyataan berskala negatif skor jawaban adalah: $\mathrm{SS}=1, \mathrm{~S}=2, \mathrm{TS}=3$ dan STS $=4$.

Angket respon siswa diberikan kepada siswa diakhir pertemuan untuk mengetahui respon siswa setelah penerapan pembelajaran IPA pada materi bencana alam menggunakan model pembelajaran Double Loop Problem Solving (DLPS). Data angket respon siswa dianalisis dengan menggunakan rumus sebagai berikut:

$$
\mathrm{R}=\frac{T S p}{T S m} \times 100 \%
$$

Sumber: (Sugiyono, 2016).

Keterangan:

$\mathrm{R}$ : rata-rata skor

TSp : total skor yang diperoleh

TSm : total skor maksimal

Hasil perhitungan persentase angket respon siswa selanjutnya akan dianalisis untuk mengetahui kriteria respon siswa terhadap penerapan model pembelajaran Double Loop Problem Solving (DLPS). Kriteria hasil angket respon siswa dapat dilihat pada table berikut ini.

Tabel 2. Kriteria Persentase Respon Siswa

\begin{tabular}{ccc} 
No & $\begin{array}{c}\text { Persentase } \\
\text { Respon Siswa }\end{array}$ & Kriteria \\
\hline 1 & $\begin{array}{c}80 \%<\mathrm{R} \leq \\
100 \%\end{array}$ & Sangat Baik \\
\hline 2 & $60 \%<\mathrm{R} \leq 80 \%$ & Baik \\
\hline 3 & $40 \%<\mathrm{R} \leq 60 \%$ & Cukup Baik \\
\hline 4 & $20 \%<\mathrm{R} \leq 40 \%$ & Kurang Baik \\
\hline 5 & $0 \% \leq \mathrm{R} \leq 20 \%$ & $\begin{array}{c}\text { Sangat Kurang } \\
\text { Baik }\end{array}$ \\
& \multicolumn{2}{c}{ Sumber }
\end{tabular}
Sumber: (Manap, 2014) 


\section{HASIL DAN PEMBAHASAN}

Adapun nilai pretest dan nilai posttest kemampuan pemecahan masalah siswa pada materi bencana alam kelas eksperimen dapat dilihat pada tabel berikut ini :

Tabel 3. Hasil Tes Uraian Siswa

\begin{tabular}{cccc} 
No & \multirow{2}{*}{$\begin{array}{c}\text { Ketuntasan } \\
\text { Individual }\end{array}$} & \multicolumn{2}{c}{$\begin{array}{c}\text { Kelas Eksperimen } \\
\text { (VII A) }\end{array}$} \\
\cline { 3 - 4 } & Pretest & Posttest \\
\hline 1 & $\begin{array}{c}\text { Tuntas } \\
(\geq 75)\end{array}$ & 0 Siswa & 22 Siswa \\
\hline 2 & $\begin{array}{c}\text { Tidak Tuntas } \\
(<75)\end{array}$ & 26 Siswa & 4 Siswa \\
\hline 3 & $\begin{array}{c}\text { Rata-Rata } \\
\text { Nilai Tes }\end{array}$ & 50,90 & 79,49 \\
\hline 4 & Kategori Tes & Cukup & Tinggi \\
\hline & Jumlah Siswa & 26 Siswa &
\end{tabular}

Hasil tes kemampuan pemecahan masalah siswa pada materi bencana alam didapat melalui tes uraian yang berupa pretest dan posttest pada kelas eksperimen. Hasil tes uraian pretest dan posttest yang berjumlah 15 soal digunakan untuk mengetahui kemampuan pemecahan masalah siswa. Nilai pretest dan nilai posttest kemampuan pemecahan masalah siswa dihitung menggunakan rumus ketuntasan indikator secara individual.

Berdasarkan tabel 2 di atas menunjukkan bahwa siswa pada kelas VII A yang merupakan sampel penelitian pada nilai pretest tidak ada siswa yang mendapat nilai tuntas. Sedangkan pada nilai posttest siswa yang mendapat nilai tuntas terdapat 22 siswa dan tidak tuntas sebanyak 4 siswa. Soal pretest diberikan sebelum kelas ekspserimen diberikan pembelajaran. Hasil analisis ketuntasan individual kemampuan pemecahan masalah siswa pada tabel menunjukkan bahwa hasil nilai pretest dari 26 siswa yang mengikuti tes jumlah siswa yang tuntas adalah 0 siswa dan tidak tuntas adalah 26 siswa dengan rata-rata nilai tes 50,90 kategori cukup. Ketuntasan individual siswa dilihat dari nilai tes yang mencapai nilai KKM mata pelajaran IPA yang telah ditentukan oleh sekolah yaitu $\geq 75$. Hasil nilai pretest pada kelas eksperimen dalam skala rata-rata sudah tergolong cukup, meskipun secara indivudual 100\% siswa mendapat nilai tidak tuntas. Hal tersebut dikarenakan pengetahuan awal siswa terhadap materi bencana alam khususnya terjadinya gempa bumi dan gunung berapi masih sangat kurang sehingga banyak siswa yang nilainya tidak tuntas.

Soal posttest diberikan setelah kelas eksperimen diberikan pembelajaran dengan menerapkan model pembelajaran Double Loop Problem Solving (DLPS). Hasil nilai posttest pada kelas eksperimen dari 26 siswa yang mengikuti tes, jumlah siswa yang tuntas adalah 22 siswa dan tidak tuntas adalah 4 siswa dengan rata-rata nilai tes 79,49 kategori tinggi. Berdasarkan hasil analisis nilai posttest tersebut, menunjukkan bahwa kemampuan pemecahan masalah siswa lebih tinggi dibandingkan dengan nilai pretest dengan selisih rata-rata 27,59. Peningkatan kemampuan pemecahan masalah yang signifikan terjadi pada kelas eksperimen yang diberikan pembelajaran dengan menerapkan model pembelajaran Double Loop Problem Solving (DLPS).

Proses pembelajaran di kelas eksperimen yang lebih menekankan pada keterlibatan siswa secara aktif berpikir dan berdiskusi dengan menggunakan dua loop yang berbeda 
untuk menyelesaikan permasalahan yang diberikan oleh guru. Hal ini sejalan dengan pendapat Huda (2013) Pada pembelajaran Double Loop Problem Solving (DPLS), siswa didorong untuk bekerja pada dua loop pemecahan yang berbeda, akan tetapi saling terkait. Pada loop 1 siswa dituntut untuk memberikan solusi sementara, sedangkan pada loop 2 siswa dituntut untuk memberikan solusi tetap terhadap bencan alam yang dapat dijumpai dalam kehidupan. Bencana alam yang sering terjadi yaitu gempa bumi dan meletusnya gunung berapi, dalam hal ini siswa harus mampu mengatasi permasalahan-permasalah yang disebabkan terjadinya bencana alam tersebut. siswa harus mampu menganalisis penyebab terjadinya bencana, memahami permasalahan yang terjadi, memberikan solusisolusi yang sesuai jenis bencana, dan mengevaluasi jenis solusi yang diberikan.

Hasil ketuntasan indikator dan taksonomi marzano kemampuan pemecahan masalah siswa kelas eksperimen yang diperoleh dari analisis nilai siswa dapat dilihat pada table dibawah ini.
Tabel 4. Hasil Ketuntasan Indikator dan Taksonomi Marzano

\begin{tabular}{clcc} 
No & \multicolumn{1}{c}{$\begin{array}{c}\text { Indikator } \\
\text { Kemampuan } \\
\end{array}$} & \multicolumn{2}{c}{$\begin{array}{c}\text { Kelas Eksperimen } \\
\text { (VII A) }\end{array}$} \\
\cline { 3 - 4 } Pemecahan Masalah & Pretest & Posttest \\
\hline 1 & $\begin{array}{l}\text { Memahami Masalah } \\
\text { (level 1 retrieval) }\end{array}$ & $64,25 \%$ & $92,91 \%$ \\
\hline 2 & $\begin{array}{l}\text { Merencanakan } \\
\text { Penyelesaian (level 2 } \\
\text { comprehension) }\end{array}$ & $46,84 \%$ & $73,34 \%$ \\
\hline 3 & $\begin{array}{l}\text { Melaksanakan } \\
\text { Rencana (level 3 } \\
\text { analysis) }\end{array}$ & $50,29 \%$ & $65,82 \%$ \\
\hline 4 & $\begin{array}{l}\text { Memeriksa Kembali } \\
\text { (level 4 knowledge } \\
\text { utilization) }\end{array}$ & $42,71 \%$ & $82,28 \%$ \\
\hline & Rata-Rata & $51,02 \%$ & $78,59 \%$
\end{tabular}

Tabel diatas menunjukkan bahwa ratarata nilai pretest yaitu $51,02 \%$ sedangkan ratarata nilai posttest yaitu 78,59\%. Hasil tersebut menunjukkan bahwa rata-rata nilai kemampuan akhir pemecahan masalah siswa pada materi bencana alam kelas eksperimen lebih tinggi nilai posttest dibandingkan nilai pretest dengan selisih persentase sebesar $27,57 \%$. Selain itu, hasil analisis pretest dan posttest indikator dan taksonomi marzano kemampuan pemecahan masalah siswa dapat dilihat pada grafik berikut ini

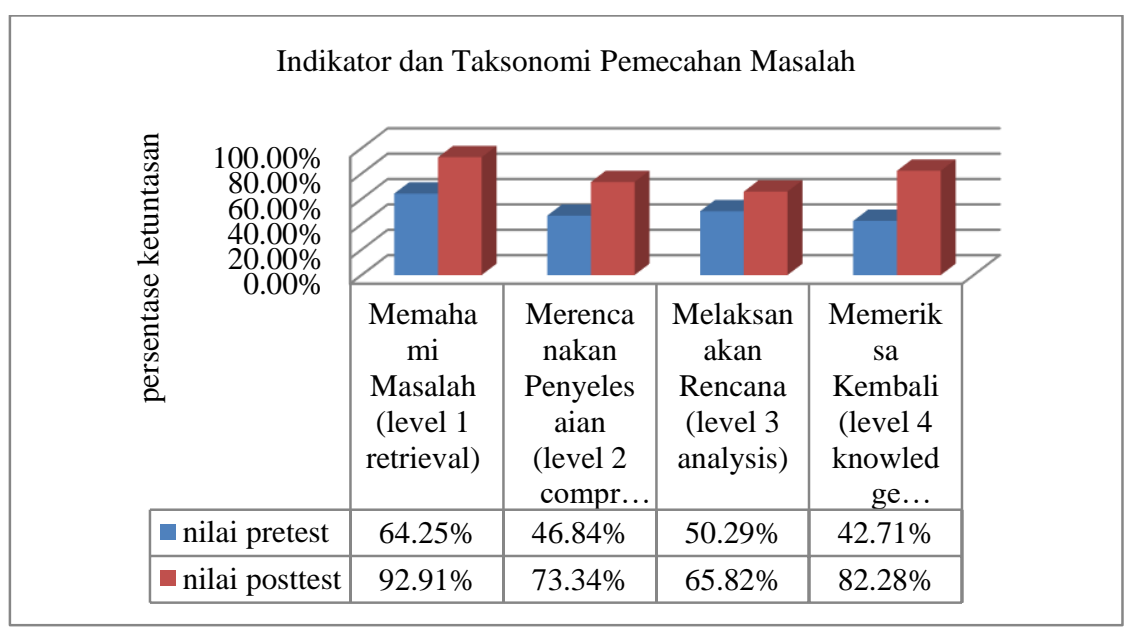

Gambar 2. Grafik Ketuntasan indikator Pemecahan Masalah dan Taksonomi Marzano 
Hasil analisis pretest dan posttest indikator kemampuan pemecahan masalah pada grafik diatas menunjukkan bahwa indikator 1 memahami masalah persentase nilai pretes tsebesar $64,25 \%$ dan nilai posttest sebesar 92,91\%. Indikator 2 merencanakan penyelesaian masalah dengan persentase nilai pretest sebesar $46,84 \%$ dan nilai posttest sebesar 73,34\%. Hasil persentase nilai pada kedua indikator pemecahan masalah pada materi bencana alam, menunjukkan peningkatan nilai siswa dari pretest ke posttes. Hal ini sejalan dengan dengan teori kontruktivisme yaitu siswa dapat berpikir untuk menyelesaikan masalah, memberikan ide, dan membuat keputusan, siswa terlibat secara langsung dengan aktif (Suyono,2014). Penerapan taksonomi marzano sebagai acuan dalam penyusunan tes juga memberikan pengaruh yang positif karena berkaitan dengan tingkat kesulitan siswa dalam berpikir untuk menyelesaikan permasalahan.

Hasil indikator 3 melaksanakan rencana penyelesaian masalah dengan persentase nilai pretest sebesar $50,29 \%$ dan nilai posttest sebesar 65,82\%. Indikator 4 memeriksa kembali proses penyelesaian masalah dengan persentase nilai pretest sebesar $42,71 \%$ dan nilai posttest sebesar $82,28 \%$. Pada indikator 3 dan indikator 4 nilai siswa dari pretest ke posttest juga mengalami peningkatan. Hal tersebut berkaitan dengan teori belajar bermakna Ausubel, berdasarkan teori ini, dalam proses pembelajaran IPA akan lebih bermakna jika siswa membangun konsep yang ada dalam dirinya dengan melakukan asosiasi terhadap pengalaman, fenomena-fenomena yang mereka jumpai dan fakta-fakta baru ke dalam pengertian yang telah dimiliki (Wisudawati, 2014). Siswa harus mampu menghubungkan pemahaman yang sudah dimiliki dengan pengetahuan yang baru. Adapun keterkaitan teori belajar bermakna Ausubel dengan model pembelajaran Double Loop Problem Solving (DLPS) yaitu melalui penerapan model pembelajaran tersebut siswa dituntut secara aktif untuk mendiskusikan dan menyelesaikan permasalahan yang berkaitan dengan kehidupan sehari-hari siswa.

Hasil perhitungan rata-rata pretest dan posttest indikator kemampuan pemecahan masalah materi bencana alam pada nilai pretest sebesar $50,89 \%$ dan nilai posttest $79,48 \%$. Berdasarkan hasil tersebut diketahui bahwa kemampuan indikator pemecahan masalah siswa pada nilai posttest lebih tinggi dibandingkan dengan nilai pretest dengan selisih sebesar 28,9\%. Hal ini merupakan dampak diterapkannya model pembelajaran Double Loop Problem Solving (DLPS) sehingga siswa dapat meningkatkan nilai pada posttest. Penerapan model pembelajaran Double Loop Problem Solving (DLPS) membuat siswa lebih aktif dalam pembelajaran dan mampu bekerja sama dengan baik untuk berdiskusi dalam kelompok.

Pembelajaran dengan menggunakan model pembelajaran Double Loop Problem Solving (DLPS) dapat membantu siswa mengaitkan materi pelajaran dengan permasalahan di kehidupan sehari-hari sehingga pembelajaran menjadi lebih bermakna dan siswa mampu mengaplikasikan pengetahuannya dalam kehidupan. Proses 
pembelajaran bermakna dapat membuat siswa mengaitkan informasi baru dengan informasi lama yang mereka miliki melalui kegiatan pemecahan masalah. Pernyataan ini sejalan dengan pemikiran Priansa (2016) pembelajaran pemecahan masalah merupakan pendekatan yang sangat efektif untuk mengajarkan proses berpikir tingkat tinggi, memproses informasi yang telah dimilikinya, dan membantu peserta didik untuk membangun sendiri pengetahuannya.

$$
\text { Hasil analisis keterlaksanaan }
$$

pembelajaran dengan menggunakan model pembelajaran Double Loop Problem Solving (DLPS) pada kelas eksperimen yang diperoleh dari rumus dengan cara banyaknya langkah yang terlaksana dibagi jumlah langkah keseluruhan dalam setiap pertemuan dapat dilihat pada tabel dibawah ini :
Tabel 5. Hasil Analisis Keterlasanaan Pembelajaran

\begin{tabular}{ccccc} 
& Pelaksanaan & \multicolumn{2}{c}{ Persentase } & \\
\cline { 3 - 4 } & $\begin{array}{c}\text { Pembelajara } \\
\mathbf{n}\end{array}$ & $\mathbf{0 1}$ & $\mathbf{0 2}$ & \\
\hline 1 & Pertemuan I & $62,16 \%$ & $59,46 \%$ & Baik \\
\hline 2 & Pertemuan II & & & $\begin{array}{c}\text { Sangat } \\
\text { Baik }\end{array}$ \\
\hline 3 & Pertemuan III & $83,87 \%$ & $83,87 \%$ & $\begin{array}{c}\text { Sangat } \\
\text { Baik }\end{array}$ \\
\hline Total Rata-Rata & $90,00 \%$ & $90,00 \%$ & $78,23 \%$ & $\begin{array}{c}\text { Sangat } \\
\text { Baik }\end{array}$ \\
Keterangan: & & & \\
O1= Observer 1 (Guru IPA di SMPN 4 Bangkalan) & \\
O2= Observer 2 (Mahasiswa IPA) &
\end{tabular}

Berdasarkan tabel diatas dapat diketahui jumlah total rata-rata keterlaksanaan pembelajaran pada mata pelajaran IPA menggunakan model pembelajaran Double Loop Problem Solving (DLPS) di kelas eksperimen sebesar 78,23\% dengan kriteria sangat baik. Selain itu, hasil analisis keterlaksanaan pembelajaran dapat dilihat pada grafik yang ditunjukkan pada gambar di bawah ini.

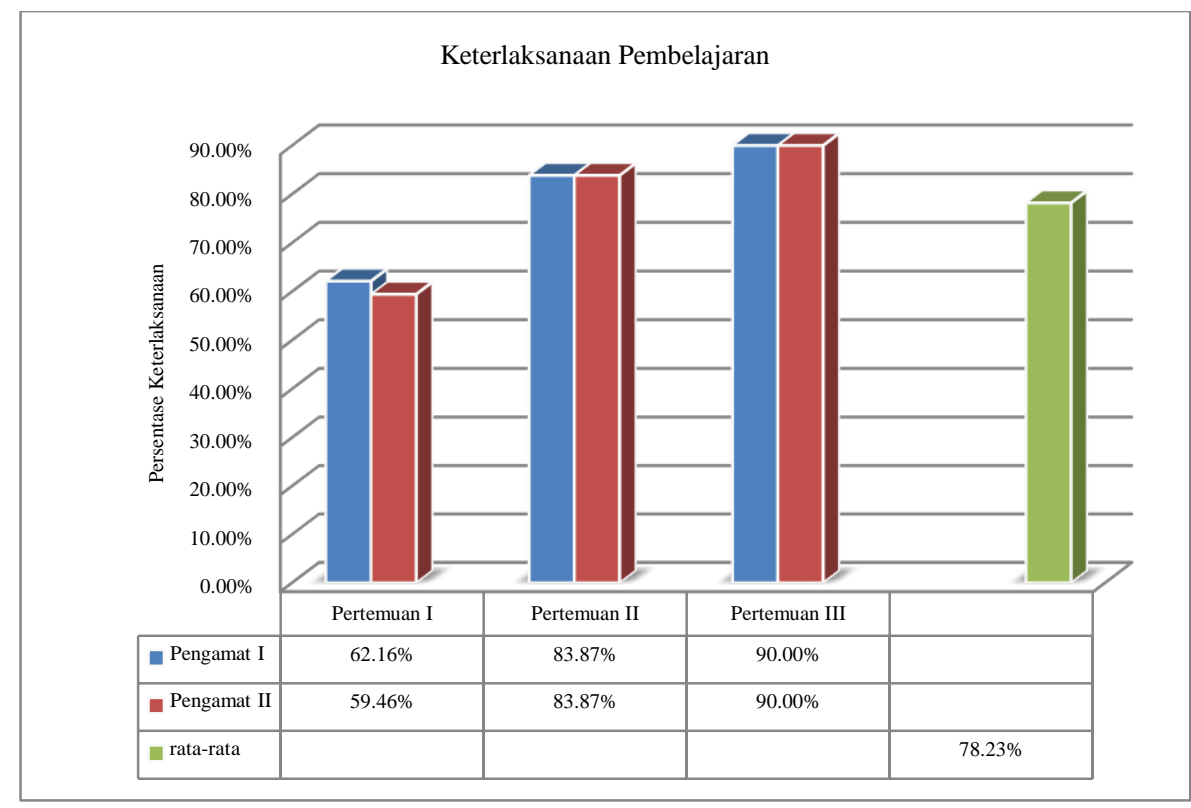

Gambar 3. Grafik Keterlaksanaan Pembelajaran 
Kegiatan pembelajaran menggunakan model Double Loop Problem Solving (DLPS) terbagi menjadi tiga bagian yaitu pendahuluan, kegiatan inti dan penutup. Pembelajaran pada tahap pendahuluan dilakukan dengan memberikan salam pembuka, membaca doa bersama-sama, menyampaikan tujuan pembelajaran dan memotivasi siswa. Pemberian motivasi belajar menekankan terhadap permasalah bencana alam yang terjadi pada kehidupan sehari-hari, sehingga siswa dapat terlibat aktif untuk memecahkan permasalahan tersebut. Terutama dalam hal pemecahan masalah, karena sejatinya dalam kehidupan kita pasti menjumpai beberapa permasalahan yang harus dipecahkan. Oleh karena itu, dibutuhkan kemampuan pemecahan masalah yang harus selalu ditingkatkan. Permasalahan bencana alam yang harus diselesaikan siswa yaitu terjadinya gempa bumi dan meletusnya gunung berapi.

Kegiatan inti pada model pembelajaran Double Loop Problem Solving (DLPS) terdiri dari langkah yang berupa menyampaikan materi, membentuk kelompok, memberikan masalah, menyelesaikan masalah secara kelompok dengan dua loop yang berbeda dan presentasi hasil diskusi kelompok. Kegiatan pembelajaran dengan melibatkan siswa untuk memahami dan mengatasi terjadinya bencana alam. Masing-masing kelompok mempresentasikan hasil diskusinya di depan kelas, kelompok yang lain mengevaluasi hasil kerja kelompok yang sedang presentasi. Pelaksanaan pembelajaran sesuai dengan langkah-langkan model pembelajaran Double Loop Problem Solving (DLPS). Menurut
Budiyanto (2016) langkah-langkah dalam penyelesaian masalah yang termasuk dalam kriteria model pembelajaran DLPS adalah sebagai berikut: menuliskan pernyataan masalah awal, mengelompokkan gejala, menuliskan pernyataan masalah yang telah direvisi, mengidentifikasi kausal, implementasi solusi, identifikasi kausal utama, menentukan pilihan solusi utama, dan implementasi solusi utama.

Kegiatan penutup dilakukan dengan merangkum materi yang telah dipelajari, mengingatkan siswa untuk mempelajari materi selanjutnya, membaca berdoa bersama-sama dan guru menutup pembelajaran dengan mengucapkan salam. Semua tahapan kegiatan pembelajaran yang diuraikan telah dilakukan selama kegiatan penelitian di kelas eksperimen dengan menggunakan model pembelajaran Double Loop Problem Solving (DLPS). Total rata-rata persentase keterlaksanaan pembelajaran IPA sebesar $78,23 \%$ dengan kriteria sangat baik. Hal ini sejalan dengan pendapat Marnita (2013) mengemukakan bahwa persentase $75 \%<\mathrm{K} \leq 100 \%$ kriteria sangat baik. Proses pembelajaran yang terlaksana dengan baik selama kegiatan pembelajaran di kelas eksperimen berpengaruh signifikan terhadap kemampuan pemecahan masalah siswa pada materi bencana alam. Penerapan model pembelajaran Double Loop Problem Solving (DLPS) siswa dituntut untuk memecahkan masalah dengan memberikan solusi sementara dan solusi tetap dengan dua loop yang berbeda.

Setelah diterapkannya pembelajaran dengan model Double Loop Problem Solving 
(DLPS), pada pertemuan ketiga yang pelajaran IPA pada materi bencana alam merupakan pertemuan terakhir siswa diberikan menggunakan model pembelajaran Double kuisioner yang berupa angket respon siswa Loop Problem Solving (DLPS) di kelas terhadap pelaksanaan pembelajaran. Hasil eksperimen dapat dilihat pada tabel di bawah analisis angket respon siswa pada mata ini.

Tabel 6. Hasil Analisis Angket Respon Siswa

\begin{tabular}{|c|c|c|c|c|c|c|c|}
\hline \multirow{2}{*}{ No } & \multirow{2}{*}{ Indikator Angket } & \multicolumn{3}{|c|}{ Skala Positif } & \multicolumn{3}{|c|}{ Skala Negatif } \\
\hline & & $\begin{array}{l}\text { No. } \\
\text { Item }\end{array}$ & $\begin{array}{l}\text { Persen } \\
\text { tase(\%) }\end{array}$ & Kriteria & $\begin{array}{l}\text { No. } \\
\text { Item }\end{array}$ & $\begin{array}{l}\text { Persen } \\
\text { tase(\%) }\end{array}$ & Kriteria \\
\hline 1. & Motivasi siswa & $\begin{array}{l}1(+) \\
3(+) \\
7(+)\end{array}$ & 86,54 & $\begin{array}{l}\text { Sangat } \\
\text { Baik }\end{array}$ & $\begin{array}{l}2(-) \\
4(-) \\
8(-)\end{array}$ & 85,90 & $\begin{array}{c}\text { Sangat } \\
\text { Baik }\end{array}$ \\
\hline 2. & $\begin{array}{lr}\text { Ketertarikan } & \text { siswa } \\
\text { mengikuti } & \text { proses } \\
\text { pembelajaran } & \end{array}$ & $\begin{array}{l}5(+) \\
9(+)\end{array}$ & 88,46 & $\begin{array}{l}\text { Sangat } \\
\text { Baik }\end{array}$ & $\begin{array}{c}6(-) \\
10(-)\end{array}$ & 85,10 & $\begin{array}{c}\text { Sangat } \\
\text { Baik }\end{array}$ \\
\hline 3. & $\begin{array}{l}\text { Konsentrasi siswa } \\
\text { dalam belajar }\end{array}$ & $\begin{array}{l}11(+) \\
15(+)\end{array}$ & 88,46 & $\begin{array}{l}\text { Sangat } \\
\text { Baik }\end{array}$ & $\begin{array}{l}12(-) \\
16(-)\end{array}$ & 85,58 & $\begin{array}{l}\text { Sangat } \\
\text { Baik }\end{array}$ \\
\hline 4. & $\begin{array}{l}\text { Pemahaman siswa } \\
\text { terhadap materi } \\
\text { setelah pembelajaran } \\
\text { mengunakan model } \\
\text { pembelajaran DLPS }\end{array}$ & $\begin{array}{l}13(+) \\
17(+) \\
19(+)\end{array}$ & 87,18 & $\begin{array}{l}\text { Sangat } \\
\text { Baik }\end{array}$ & $\begin{array}{l}14(-) \\
18(-) \\
20(-)\end{array}$ & 89,42 & $\begin{array}{c}\text { Sangat } \\
\text { Baik }\end{array}$ \\
\hline \multicolumn{2}{|c|}{ Rata-rata total Respon Siswa } & \multicolumn{6}{|c|}{$87,08 \%$} \\
\hline
\end{tabular}

Berdasarkan tabel diatas, dapat diketahui positif terhadap pelaksanaan pembelajaran. total persentase respon siswa di kelas Hasil analisis angket respon siswa juga dapat eksperimen sebesar $87,08 \%$ dengan kriteria dilihat pada grafik yang ditunjukkan Gambar di sangat baik. Siswa memberikan respon yang bawah ini.

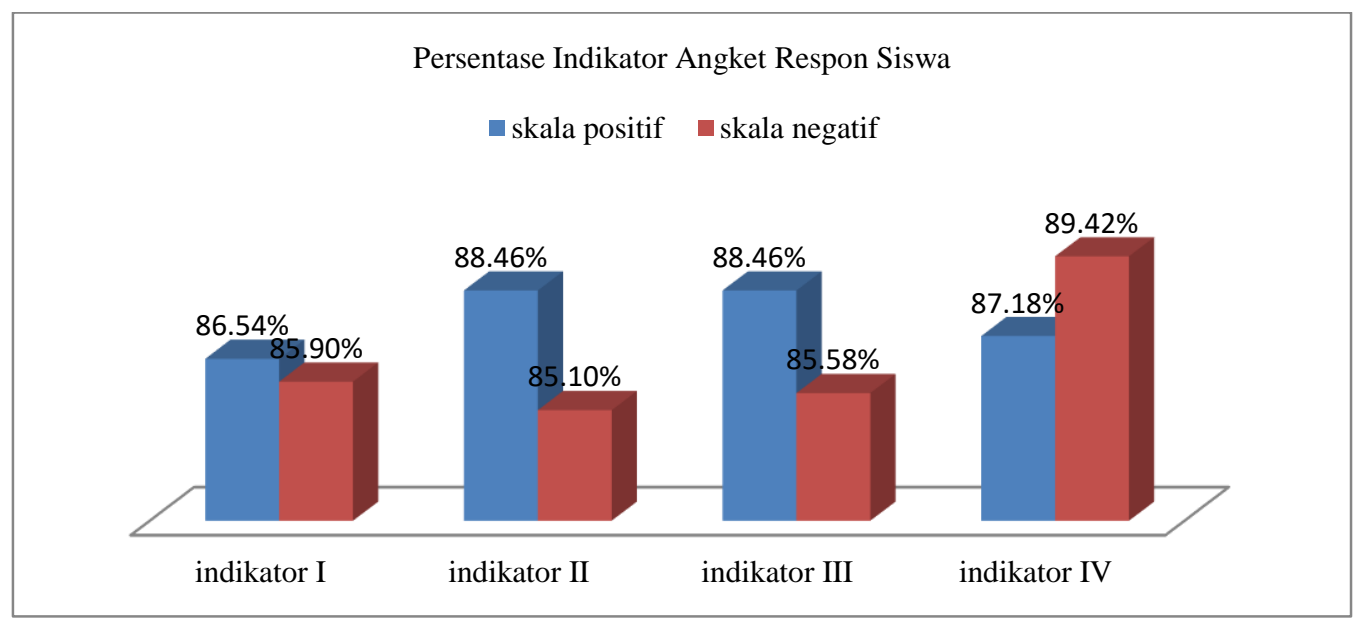

Gambar 4. Grafik Analisis Angket Respon Siswa 
Total rata-rata persentase angket respon siswa secara keseluruhan pada mata pelajaran IPA menggunakan model pembelajaran Double Loop Problem Solving (DLPS) adalah sebesar $87,08 \%$ dengan kriteria respon sangat baik. Hal tersebut sejalan dengan pendapat yang dikemukakan oleh Marnita (2013) yang mengemukakan bahwa persentase $80 \%<\mathrm{R} \leq$ $100 \%$ dengan kriteria sangat baik. Model pembelajaran Double Loop Problem Solving (DLPS) dapat membuat setiap anggota kelompok saling belajar mengenai strategi atau langkah-langkah pemecahan masalah satu sama lain.

Model pembelajaran Double Loop Problem Solving (DLPS) menuntut seorang siswa untuk mampu memberikan solusi pada permasalahan-permasalahan yang ada khususnya permasalahan yang disebabkan adanya bencana alam yang berupa gempa bumi dan meletusnya gunung berapi. Solusi yang diberikan dapat berupa solusi sementara dan solusi tetap. Siswa memberikan respon yang sangat baik terhadap kegiatan pembelajaran model Double Loop Problem Solving (DLPS) berpengaruh positif terhadap kemampuan pemecahan masalah siswa. Hal ini dibuktikan berdasarkan kesimpulan hasil penelitian bahwa model pembelajaran Double Loop Problem Solving (DLPS) berpengaruh signifikan terhadap kemampuan pemecahan masalah siswa pada mata pelajaran IPA materi bencana alam di kelas VIIA SMP Negeri 4 Bangkalan.

\section{KESIMPULAN}

Berdasarkan hasil analisis data dan pembahasan dalam penelitian, maka diperoleh beberapa kesimpulan bahwa terdapat pengaruh model pembelajaran Double Loop Problem Solving (DLPS) terhadap kemampuan pemecahan masalah siswa pada materi bencana alam dengan signifikansi 5\% mendapatkan hasil $t_{\text {hitung }}<t_{\text {tabel }}(-24,550<$ 2,059). Berdasarkan kriteria pengujian hipotesis, maka hipotesis $\mathrm{H}_{\mathrm{o}}$ ditolak dan $\mathrm{H}_{\mathrm{a}}$ diterima. Hasil keterlaksanaan pembelajaran dengan dua observer pada penerapan model pembelajaran Double Loop Problem Solving (DLPS) mencapai persentase $78,23 \%$ sehingga hasil pembelajaran dikategorikan sangat baik. Persentase rata-rata respon siswa terhadap pembelajaran yaitu $87,08 \%$ dengan kriteria sangat baik. Siswa memberikan respon yang positif terhadap penerapan model pembelajaran Double Loop Problem Solving (DLPS). Ratarata persentase nilai pretest siswa yaitu $51,02 \%$ sedangkan rata-rata persentase nilai posttest yaitu $78,59 \%$. Hal tersebut menunjukkan bahwa nilai rata-rata kemampuan akhir pemecahan masalah siswa materi bencana alam lebih tinggi nilai posttest dibandingkan nilai pretest dengan selisih sebesar 27,57\%. Peningkatan kemampuan pemecahan masalah siswa pada materi bencana alam merupakan pengaruh dari diterapkannya model pembelajaran Double Loop Problem Solving (DLPS).

\section{SARAN}

Hasil penelitian ini dapat dijadikan sebagai penelitian relevan untuk penelitian 
selanjutnya. Namun, variabel terikat dalam penelitian ini dapat diganti dengan variabel terikat lainnya sehingga dapat memberikan hasil penelitian yang bervariasi. Jika ada penelitian dengan tema yang serupa, diharapkan dapat mengembangkan penelitian ini karena keadaan dapat berubah sesuai kondisi lapangan.

\section{DAFTAR PUSTAKA}

Budiyanto, A. K. 2016. Sintaks 45 Metode Pembelajaran dalam Student centered Learning (SCL). Malang: Universitas Muhammadiyah Malang.

Huda, M. 2013. Model - Model Pengajaran dan Pembelajaran. Yogyakarta : Pustaka Pelajar.

Manap, S. Dkk. 2014. Interpersonal Skill (tips membangun komunikasi dan Relasi) Bandung : Mujahid Press

Marnita. 2013. Peningkatan Keterampilan Proses Sains Melalui Pembelajaran Kontekstual pada Mahasiswa Semester I Materi Dinamika. Jurnal Pendidikan Fisika Indonesia. Vol 3, No 1.
Nuraini, dkk.2016. Analisis Permasalahan Guru Terkait Perangkat Pembelajaran Berbasis Model Inquiry dan Permasalahan Siswa Terkait Kemampuan Pemecahan Masalah dalam Pembelajaran Biologi di SMA. Jurnal Pengajaran MIPA Volume 18, No. 1.

Priansa, D. J. 2016. Pengembangan Strategi \& Model Pembelajaran. Bandung: Harmoni.

Rosidi, I. 2015. Pengembangan Perangkat pembelajaran IPA Terpadu Tipe Integrated untuk Mengetahui Ketuntasan Hasil Belajar IPA Siswa SMP pada Topik Pengelolaan Lingkungan. Jurnal Pena Sains Vol 2 No. 1.

Sugiyono. 2016. Metode Penelitian Pendidikan Kuantitatif, Kualitatif, dan R\&D. Bandung: CV Alfabeta.

Suyono dan Hariyanto. 2014. Belajar dan Pembelajaran: Teori dan Konsep Dasar. Bandung: Remaja Rosdakarya.

Wisudawati, A. W. \& Eka S. 2014. Metodologi Pembelajaran IPA. Jakarta: Bumi Aksara. 